\title{
Keiji Nishitani and Karl Rahner: A Response to Nihility
}

Heidi Ann Russell

hrussell@luc.edu

Follow this and additional works at: https://ecommons.luc.edu/ips_facpubs

Part of the Religion Commons

\section{Recommended Citation}

Russell, HA. "Keiji Nishitani and Karl Rahner: A Response to Nihility." Buddhist-Christian Studies 28, 2008.

This Article is brought to you for free and open access by the Faculty Publications and Other Works by Department at Loyola eCommons. It has been accepted for inclusion in Institute of Pastoral Studies: Faculty Publications and Other Works by an authorized administrator of Loyola eCommons. For more information, please contact ecommons@luc.edu.

\section{(c) $(\ominus)$}

This work is licensed under a Creative Commons Attribution-Noncommercial-No Derivative Works 3.0 License. (c) University of Hawai'i Press, 2008. 


\title{
Keiji Nishitani and Karl Rahner: A Response to Nihility
}

\author{
Heidi Ann Russell \\ Institute of Pastoral Studies \\ at Loyola University Chicago
}

In his essay "Kenosis and Emptiness," Buddhist scholar Masao Abe states that "the necessity of tackling the Buddhist-Christian dialogue not merely in terms of interfaith dialogue, but also as an inseparable part of the wider sociocultural problem of religion versus irreligion has become more and more pressing in the past few decades." ${ }^{1}$ From Keiji Nishitani's perspective a culture of self-centeredness has developed out of the inability of many people to move beyond a sense of nihilism in their lives. Furthermore, technological advances and an increased understanding of the laws of nature have allowed humans to manipulate those laws for their own purposes. In this development, Nishitani believes that "the perversion that occurred in the original relationship of man to the laws of nature has taken the shape of a fundamental intertwining of the mechanization of man and his transformation into a subject in pursuit of its desires, at the ground of which nihility has opened up as a sense of the meaninglessness of the whole business." 2

Both Nishitani and Karl Rahner see in the development of science and technology a tendency to manipulate the laws of nature for one's own benefit in a way that increases the self-centeredness and self-absorption of humankind while at the same time devaluing humanity and engendering an attitude of meaninglessness. In a world today that is confronted with issues such as war and global warming and in which religious communities are trying to make sense out of scientific issues such as stem cell research and cloning, the ability to address a nihilistic standpoint that sees the surrounding world as simply being at human disposal has never been more crucial. So how does one confront this crisis of a nihilistic culture? Abe recommends that both Buddhism and Christianity need "to pursue a fundamental reorganization in characterizing their faith such that the prevailing basic assumptions are drastically changed-for example, a revolutionary reinterpretation of the concept of God in Christianity and the concept of Emptiness in Buddhism-thereby allowing a new paradigm or model of understanding to emerge." ${ }^{3}$ The concept of emptiness or nothingness in Keiji Nishitani's Religion and Nothingness and the concept of God as incomprehensible mystery in the theology of Karl Rahner ${ }^{4}$ could allow for the

Buddhist-Christian Studies 28 (2008). (C) by University of Hawai'i Press. All rights reserved. 
emergence of a model of understanding that addresses the problem of irreligion or nihility from an interreligious perspective. ${ }^{5}$ While in no way negating the very real dissimilarities between the concepts of Nishitani and Rahner or the respective religious traditions of which they are a part, one need not think of their concepts as diametrically opposed to one another in such a way that dialogue is impossible. To that effect, this essay will explore the common ground between Nishitani's concept of 'sünyata $\bar{a}^{6}$ (often translated or defined as $k u /$ emptiness or $m u /$ nothingness) and Rahner's incomprehensible $\operatorname{God}^{7}$ based on their interpretations of the human experience of meaninglessness and the need for a surrender of the self that manifests itself in one's loving relationship with others. Common human experience, such as the experience of death or meaninglessness, and the interpretations of that experience found in various religions can provide ground from which to begin interreligious dialogue. One can search for a connection between the religious concepts by looking at the way they make sense out of a common affective experience without requiring an absolute identity between the cognitive religious concepts themselves. ${ }^{8}$ The important point of comparison is not manufacturing a false identity between the concepts, but the way the concepts work within the living communities to move one to volitive action. In this way the practical or ethical implications of the concepts and how they are lived out in the world become the focus. In the work of Nishitani and Rahner, that common human experience is the meaninglessness encountered in the world today and the call for a selfless love that will transcend such meaninglessness. In their roles as philosopher-theologians, both Nishitani and Rahner have probably had more influence on individuals or leaders within certain Buddhist and Christian communities rather than by having specific living communities that are founded on or dedicated to their thought. ${ }^{9}$ Working out the practical or ethical implications of their thought thus shows how they can continue to be relevant to communities of faith today.

\section{EMPTINESS IN THE THOUGHT OF KEIJI NISHITANI}

Nishitani's understanding of emptiness or absolute nothingness in his book Religion and Nothingness ${ }^{10}$ can be explicated by looking at how Nishitani understands the human experience of nihility, how he sees emptiness as a reality that grounds even the experience of nihility, and finally the resultant need for an understanding of the non-self. Nishitani speaks of the experience of nihility as an existential of human existence. The experience of nihility is part of what it means to be human, and it is the point at which one can begin the religious quest. Nishitani describes nihility as "that which renders meaningless the meaning of life. When we become a question to ourselves and when the problem of why we exist arises, this means that nihility has emerged from the ground of our existence and that our very existence has turned into a question mark." 11 At this point of meaninglessness one questions the purpose of life and of human existence. Nishitani attributes this experience and the deepening of awareness that results from the experience to the common human experience of death. He states that "our life runs up against death at its every step; we keep one foot planted in the vale of death at all times. Our life stands poised at the brink of the 
abyss of nihility to which it may return at any moment. Our existence is an existence at one with non-existence, swinging back and forth over nihility, ceaselessly passing away and ceaselessly gaining its existence. This is what is called the "incessant becoming' of existence." 12

It is precisely when one runs up against the frailty of human existence, the realization that life can end much more quickly than it began, that one begins to question whether or not life is meaningful. For Nishitani, this experience of death and finiteness causes a void or an abyss to appear, in the face of which "not one of all the things that had made up the stuff of life until then is of any use." 13 Everything that has given one's life meaning up to that point suddenly ceases to be meaningful as one looks at the gaping hole of nonexistence on whose brink one stands. It is at this point, Nishitani maintains, that all things lose their necessity and utility. ${ }^{14}$ One no longer asks the purpose of things for oneself - that is, in what way are they necessary and useful to me-but rather one begins to ask what is one's own purpose. ${ }^{15}$ This question that one is, for Nishitani, is the beginning of the religious quest. To stop at the point of the yawning abyss of meaninglessness is nihilism, but Nishitani insists that one must look to that which grounds even the abyss of nihilism, absolute nothingness or śūnyatā.

In the glossary of the English translation of Nishitani's Religion and Nothingness, Jan Van Bragt defines emptiness or śünyatā as follows: "In accord with the image suggested by the Chinese character, it is said to be 'skylike' and is compared in the text to an all-encompassing cosmic sky." 16 In Religion and Nothingness Nishitani uses both "emptiness" and "absolute nothingness" to refer to this reality. According to Waldenfels, Nishitani eventually comes to replace the term "absolute nothingness" with the term "emptiness" in his work "in memory of" Nāgārjuna. ${ }^{17}$ To describe emptiness, it is first necessary to understand what emptiness is not. On the one hand, Nishitani maintains that emptiness is not a nihilistic, positivistic, or materialistic atheism. ${ }^{18}$ On the other hand, he also denies that it is theism or pantheism. ${ }^{19}$ Nishitani objects to the fact that "'nothingness' is generally forced into a relationship with 'being' and made to serve as its negation, leading to its conception as something that 'is' nothingness because it 'is not' being." " 20 This understanding of nothingness would be nihilistic. Nishitani maintains that "insofar as one stops here, nothingness remains a concept, a nothingness only in thought. Absolute nothingness wherein even that 'is' is negated, is not possible as a nothingness that is thought but only a nothingness that is lived." ${ }^{21}$ For Nishitani nothingness must have ethical implications. However, despite these objections to a nothingness that is thought, unlike Nāgārjuna, Nishitani does give a positive content to the understanding of nothingness. Nishitani describes emptiness as encompassing all things, including nihility. He states that "it is a cosmic sky enveloping the earth and man and countless legions of stars that move and have their being within it. It lies beneath the ground we tread, its bottom reaching beneath the valley's bottom. If the place where the omnipresent God resides be called heaven, then heaven would also have to reach beneath the bottomless pit of hell: heaven would be an abyss for hell. This is the sense in which emptiness is an abyss for the abyss of nihility." ${ }^{22}$ Going beyond Nishitani's definition, the term emptiness as it is 
described here implies the concept of openness or space. This emptiness or openness holds all things within it. It is the womb of God that encompasses and makes room within it for that which is other.

Nishitani himself, in his efforts to build a bridge between Eastern and Western thought, connects the idea of emptiness to Christian doctrine. Nishitani connects this understanding of selflessness or śünyatā to the nondifferentiating love of God in Christianity. He uses "the biblical analogy that tells us there is no such thing as selfish or selective sunshine" 23 to describe such nondifferentiating love. As the sun shines on the good and the bad alike, so too does the love of God. He identifies this Christian analogy with the Great Compassionate Heart of Buddhism. ${ }^{24}$ By reason of this nondifferentiating love, Nishitani does not call God personal or impersonal but transpersonal, the ground of a personal relationship with God. He understands God as impersonally personal or personally impersonal, as an impersonal person or a personal nonperson. ${ }^{25}$

The idea of súunyatā grounds the idea of the transpersonal God. Śñnyatā is the field that provides the space for relationships of any kind, including the relationship between a person and God. He states, "it is only on the field of this same emptiness that God and man, and the relationships between them, are constituted in a personal Form, and that their respective representations are made possible." ${ }^{26}$ Nishitani draws on Meister Eckhart's understanding of God and Godhead in order to make this distinction between God and the representation of God. The emptiness of God allows us to conceive of God in a personal way and to relate to that representation of God. Emptiness is that which is the most near to us and the most far from us, most personal and yet nondifferentiating. Nishitani uses the image of angles to describe it as the point where $0^{\circ}$ is at the same time $360^{\circ}$, the point at which the absolute near side is also the absolute far side. ${ }^{27}$

The idea of God making room for that which is other is also seen in Nishitani's understanding of the Christian doctrine of creatio ex nibilo. He understands this doctrine in terms of the absolute distinctness of all things from God and their grounding in nibilum, yet at the same time being sustained in existence through God. ${ }^{28}$ Nishitani explains the omnipresence and absolute immanence of God through this doctrine of creation from nothing as that which makes God absolutely transcendent. ${ }^{29}$ Nishitani argues that "the God before whom all of creation is as nothing makes himself present through all of creation. The Christian must be able to pick up a single pebble or blade of grass and see the same consuming fire of God and the pillar of fire, hear the same thunderous roar, and feel the same 'fear and trembling' that Moses experienced." 30 The Christian does not experience this presence of God in a pantheistic way, as if the pebble or the blade of grass is God, but experiences God precisely because the pebble or blade of grass is not God, but is created by God. Nishitani explains that "the being of the created is grounded upon a nothingness and seen fundamentally to be a nothingness. At the same time, it is an immanence of absolute affirmation, for the nothingness of the created is the ground of its being. This is the omnipresence of God in all things that have their being as a creatio ex nihilo." ${ }^{31}$ The interdependence of absolute negation and absolute affirmation grounds the Christian's need and ability 
to die to self and live in God. ${ }^{32}$ Such an understanding of the interdependence of all things grounded in their creation by God out of nothing should then have an impact on how people treat one another and the created world in which we live. No longer can one see the world and other human beings as being for one's own subjection and use; now, in the experience of God in and through what is other, one must see oneself at the service of God in and through service to God's creation. This concept will be developed in the section on Rahner's understanding of the unity of love of God and love of neighbor.

For Nishitani, however, the reality of the world is that many do not move beyond nihilism, thus causing a crisis of modern culture that results in a rampant self-centeredness. One becomes caught up in a bitter circle in which nihility becomes the ground of a self-centeredness that results in a continual devaluation of life, and thus increases the experience of meaninglessness. Nishitani notes that "with the advance of the rationalization of life, yet standing behind it, another standpoint continues to gather strength: the growing affirmation of a prereflective human mode of being that is totally non-rational and non-spiritual, the stance of the subject that locates itself on nihility as it pursues its own desires unreservedly." ${ }^{33}$ Nishitani critiques the use of technology and the ability to manipulate the laws of nature as contributing to the self-centeredness of humankind. He extends his critique to the way in which countries are governed, noting that the communist governments maintain a totalitarianism that results in the mechanization of institutions and of humans, while the liberalist governments equate the freedom of individuals with the freedom of a subject to pursue its own desires. ${ }^{34}$ Both systems are grounded on nihility and result in a humanity absorbed in meaninglessness and selfishness.

Nishitani confronts this nihilistic culture with the belief that there is a reality beyond nihility, and that reality is śm nyatā, the emptiness that grounds the experience of nihility. The problem with nihilism is that it objectifies nothingness, making it into some "thing." 35 Nishitani explains: "nihility comes to be represented as something outside of the existence of the self and all things, as some 'thing' absolutely other than existence, some 'thing' called nothingness." ${ }^{36}$ Nishitani advocates a "lived nothingness" that manifests itself in selflessness or the non-self instead of a nihility that results in selfishness.

The idea of lived nothingness is a call to conversion in which "the negation of person-centeredness must amount to an existential self-negation of man as person." ${ }^{37}$ But for Nishitani, "in this kind of existential conversion, the self does not cease being a personal being. What is left behind is only the person-centered mode of being wherein the person is caught up in itself. In that very conversion the personal mode of being becomes more real, draws closer to the self, and appears in its true suchness. When person-centered self-prehension is broken down and nothingness is really actualized in the self, personal existence also comes really and truly to actualization in the self." ${ }^{38}$ It is only in the negation of the self as a wholly independent entity that one is able to be truly in relationship. In such a negation of self, one no longer understands oneself as a subject over and against all other things, things that are then seen as objects. Rather, one comes to understand the interrelatedness of all things and 
the fact that it is precisely that interrelatedness that allows one to have and be a "self." The coming to awareness of one's interrelatedness is intrinsically connected to the experience of nihility in which one realizes that for friends and strangers alike, one can never know where they came from or where they are going, thus both are to the same degree "unknown." ${ }^{39}$ For Nishitani, this nihility occurs with a field of emptiness "on which an essential encounter can take place between entities normally taken to be most distantly related, even at enmity with each other, no less than those that are most closely related." ${ }^{40}$ In a world of increasing global conflict, one must come to realize that one is most oneself in recognizing one's oneness with all others, even with one's enemies. Thus Nishitani goes on to say that "we have here an absolute self-identity in which the one and the other are truly themselves, at once absolutely broken apart and absolutely joined together. They are an absolute two and at the same time an absolute one." ${ }^{41}$ It is precisely in our differences and in the brokenness of our humanity that we should come to recognize our oneness. Note the similar ethical implications of the Christian teaching to love one's enemies and the teaching found in the story of the good Samaritan that one should not differentiate between people in deciding who is one's neighbor because all people are one's neighbor. Nishitani asserts that "this lack of selfishness is what is meant by non-ego or 'emptiness' ('śünyatā)." 42 Śünyatā, as a response to the threat of nihility in our world, must be experienced and lived. Having examined Nisitani's understanding of the human experience of nihility as grounded in śünyatā and having seen that the result of living śünyatā should be a self-negation that allows for a self-giving relationship with others, the next section turns to the theology of Karl Rahner. Nishitani provides a sound dialogue partner for Karl Rahner because they both ground their religious concepts in a response to the human experience of meaningless found in the interdependence of all creation.

\section{THE INCOMPREHENSIBLE GOD OF KARL RAHNER}

Karl Rahner maintains that the "struggle against atheism is always and foremost a struggle against a view of God which is in danger of replacing the true, incomprehensible God by a human idol." ${ }^{43} \mathrm{He}$ also points out that an alliance of religions based on what they hold in common despite their divergences could be employed in the struggle against atheism. ${ }^{44}$ His theology makes an effort to call one back to the incomprehensibility of God. This theology of the incomprehensible God allows for a dialogue between his thought and the thought of Keiji Nishitani. The common ground for the two respective understandings of reality, as was stated above, is the human experience of meaninglessness and the call for selflessness and self-surrender in the face of that meaningless.

As Nishitani saw human existence as a question of meaning, so too does Karl Rahner. Rahner, like Nishitani, sees the question that human existence is as arising from the existential experience of death and alienation. Rahner responds to the human experience of meaninglessness by explicating an understanding of God that can ground that experience in absolute meaning, thus providing the answer to the question that is human existence. 
Rahner maintains that "human existence itself makes man feel lonely, as if placed into emptiness, as if involved in an infinite fall." ${ }^{45}$ Rahner's understanding of the human experience of emptiness echoes Nishitani's understanding of the experience of nihility. Rahner describes the feeling of emptiness as being "surrounded by an infinite ocean of darkness and an immense unexplored night-always merely managing to survive from one contingency to another." 46 Like Nishitani, Rahner also associates this experience with the human reality and consciousness of death. The one experience that every human must face is death. Rahner states that the human "feels death living within him in the midst of his life. He feels how death is the final limit beyond which he himself cannot pass." ${ }^{47}$ In the face of death one begins to question the meaningfulness of human existence.

Rahner also notes that the meaninglessness and selfishness of human existence can be the consequence of modern advances in science. ${ }^{48}$ The question that is human existence arises because of the contemporary situation of living in a world in which humans put themselves at the center, seeing all other things for their own use and control, even their fellow human beings. Nishitani argues that this attitude is precisely what leads to dehumanization. Rahner notes that "we live in an age in which man actively manipulates the world and himself, in which the world, far from being thought of in concrete terms as subject to the control of heavenly powers, becomes the object of rational research and a quarry of arid facts from which man draws his materials for the construction of that world which he plans according to his own image and likeness, and where there seems to be room for wonder only where man himself is absent from the scene." ${ }^{49}$ The world that Rahner describes is one where it becomes harder to find any meaning because humanity is always placed at the center of reality instead of God. Communities of faith today must face a world in environmental crisis because of the consequences of placing all of creation at the service of humankind. Society at large, as well as faith communities, will struggle to balance the goodness of advancing scientific knowledge with the ethical implications of those advances in science and technology. Humans today have an unparalleled ability to manipulate the world around them and even manipulate humanity itself through advances in genetics and cloning. ${ }^{50}$ Abuses of human rights in situations of war and even in the market economy abound so that the destruction or devaluation of human life is too often simply understood as collateral damage. The result of such a world is a common human experience of meaninglessness.

Ideally the existential situation of meaninglessness leads to the realization that by one's very nature one is a question to which there is no answer to be found other than the incomprehensible God. As will be explained below, the answer becomes relevant in our lived reality when one understands that for Rahner the experience of the incomprehensible God is mediated through one's relation to and interdependence with the world in which we live. Rahner notes that we can remain in the comfort zone where God and reality are comprehensible, but "we can do this only with the aid of rationalistic theory and . . . the bitterness of life's frustrations bring us up continually against this marginal experience, so that at most we may wonder whether what is beyond this field of clear knowledge and autonomously practicable plans amounts to 
a fall into an abysmal meaninglessness or to being caught up by a sheltering incomprehensibility relieving us purely and simply of ourselves and our question." ${ }^{11}$ In other words, a rational, comprehensible idea of God falls short in making sense out of the experience of nihility in life. In the end one must make a choice between trusting that all of life is headed toward the ultimate meaning found in the incomprehensible mystery of God, or giving in to a nihilistic despair. ${ }^{52}$

For Rahner, the answer to the question of the meaninglessness of human existence is God. He asserts that God is meaning, but not meaning as one usually understands the term. It is not that which comes within our grasp, but rather the meaning that, as incomprehensible, grounds all concrete, comprehensible meaning. ${ }^{53}$ Rahner argues that "it is only in falling into an unfathomable abyss that we grasp the individual reality to which we can cling." "54 In Rahner's language of an abyss that grounds all of concrete knowledge, one is reminded of Nishitani's understanding of the emptiness that grounds all distinctions.

As Nishitani explains śūnyatā as absolute nearness and absolute distance, Rahner describes the incomprehensible God, seemingly so distant in the very fact of God's incomprehensibility, as precisely what is closest because it is what grounds human existence. One is reminded of Nishitani's image of angles to describe s'ünyatā as the place where $0^{\circ}$ is at the same time $360^{\circ}$. Rahner believes "the experience that the basis of man's existence is the abyss: that God is essentially the inconceivable" 55 is what grounds human transcendence. Elsewhere Rahner speaks of the human's “inescapable experience of the fact that he is grounded in the abyss of the insoluble mystery" ${ }^{56}$ and that this mystery is to be understood as fulfilling nearness. As absolute nearness, this mystery of God is not to be considered impersonal, even though God as personal is always to be understood in light of God's incomprehensibility and dissimilarity from ourselves. $^{57}$

For Rahner the result of the experience of understanding human existence as a question about the meaning of life combined with finding the answer in the incomprehensible God is the need to surrender oneself to that mystery. In doing so, one finds oneself in a stance that is very similar to Nishitani's "non-self" - that is, in a stance of giving up autonomy for love. For Rahner this stance manifests itself in the love of one's neighbor, a love that is exemplified in Jesus Christ.

Rahner maintains that the "act in which man can allow for and accept God's incomprehensibility . . . is the act of self-surrendering love trusting entirely in this very incomprehensibility, in which knowledge surpasses itself, rising to its supernature, and is aware of itself only by becoming love." ${ }^{58}$ In a world in which one is faced with the threat of meaninglessness, surrendering to the incomprehensible God that grounds all existence means recognizing the interrelatedness of all things and reaching out to all existence in love. Rahner fully realizes that such a trusting surrender is not an easy task. In fact he states that "it is easier to let oneself fall into one's own emptiness than into the abyss of the Blessed Mystery. But it is not more courageous or true." 59 In other words, nihility is an easier choice than surrendering to love, but it is precisely the more difficult task of surrendering to God that one is called to as a human person. Rahner also notes that one can never be certain if one is 
really accepting "this 'blinding' darkness into which we plunge ourselves and become incomprehensible to ourselves" or if "we are ultimately taking refuge in a desperate act of self-assertion." ${ }^{60}$

Rahner argues that even in one's "striving to assert oneself as autonomous," one always knows "the possibility of self-surrendering love," ${ }^{61}$ and for that reason one remains unhappy in one's self-autonomy. The more one asserts oneself in individualistic and autonomous ways, subjecting the world to one's own purposes, the more meaningless one finds the world to be. It is only in "the loving leap into the one possibility (accepting the incomprehensibility of God)" that "the other possibility (of isolated self-possession) no longer exists." ${ }^{62}$ In surrendering oneself to God, one gives up the self-centeredness of seeing oneself as separate from all others, and precisely in this surrender to what is other one finds oneself. This surrender to God manifests itself in the love of one's neighbor precisely because one now understands oneself as interrelated to all things through God. Rahner explains that "the experience of life is an experience of other persons, one in which material objects are encountered as elements connected with, and surrounding concrete persons and not otherwise.... The 'I' is always related to a 'Thou,' arising at the same moment in the 'Thou' as in the 'I,' experiencing itself in all cases only in its encounter with the other person." ${ }^{6} 3$ In the giving up of oneself one is able to recognize and realize one's own subjectivity as well as the subjectivity of one's neighbor-a stance that is humanizing instead of dehumanizing. ${ }^{64}$ The danger inherent in this view remains the possibility of seeing the other simply as a means to one's own self-actualization and realization of one's subjectivity. To do so, however, would be inherently self-contradicting and negate the very process that Rahner is attempting to describe in which one finds oneself only in giving oneself in love.

This giving over of oneself to the other in a way that defies all human reason is exemplified for Rahner in Jesus Christ. For Rahner the occurrence of this "irrational" love in the midst of one's everyday life is the place where "the last renunciation and the last surrender to God can occur," which in turn "admits us to a participation in the final deed of Jesus on the cross." ${ }^{65}$ Rahner understands the surrender to the incomprehensible God that manifests itself in a selfless love of one's neighbor to be the ground of a personal relationship with our incomprehensible God. He states that

we have to enter Jesus' fate and give ourselves over in faith, hope and love to his unconditional love for his fellow men and his death. We have to live and die with him in the empty darkness of his death. We shall then learn in his Spirit how to associate with God himself beyond the reality of this world, how to fall without perishing into this inexpressibly mysterious God, whose judgments are so incomprehensible, and how therefore to discover the ultimate and definitive reality beyond this life. If the Christian has a personal and direct love for Jesus and lets Jesus' life and fate become the inner form and entelechy of his own life, he will inevitably find that Jesus is the way, the truth, and the life and that he will take him to the Father. He will also discover that he is able to call the incomprehensible God Father, even though he is nameless and that 
this God, who is without a name and a way, can still be his home and give him eternal life. ${ }^{66}$

This admittedly long citation provides an excellent summary of Rahner's position. One surrenders to the incomprehensibility of God by entering into Jesus's unconditional love for humanity and his absolute surrender into God's incomprehensibility that culminated in his death. In doing so, one finds the meaning of human existence, and the God that seemed so distant in God's incomprehensibility is found to be the most near, $A b b a$, the very ground of one's existence. The answer to the experience of nihility is to recognize that our very being is grounded in interconnectedness. Rahner concludes that "on the one hand the experience of God and the experience of self are one, and on the other that the experience of self and the encounter with neighbor are one, that all these three experiences ultimately constitute a single reality with three aspects mutually conditioning one another." ${ }^{67}$ When a faith community is grounded in the oneness of self, other, and God, a countercultural approach to issues of individualism, materialism, human exploitation, and the future of the created world emerges that takes as its starting point that one's own well-being, and in fact one's very existence, is dependent on the well-being and existence of the other.

\section{CONCLUSION}

In looking at the theologies of Keiji Nishitani and Karl Rahner, one finds a point of connection at which a dialogue can occur between a Buddhist and a Christian. This point of connection is the common human experience of contemporary culture that makes one question the ultimate purpose and meaning of life. Both theologians respond with an understanding of reality, śünyatā and an incomprehensible God respectively, that grounds human existence and encompasses the emptiness that human persons experience. When one accepts either understanding of reality, the result is a surrender of self to that reality that manifests itself in an interdependence with and a radical love for all of humanity.

In looking at these similarities between Rahner's concept of God and Nishitani's concept of emptiness, it is important to remember that there cannot be a strict identity between the two concepts of reality. One important distinction to maintain between Rahner and Nishitani is that while Nishitani's primary metaphor is emptiness that surrounds the emptiness in the human person, Rahner's primary metaphor is absolute fullness as that which fills the emptiness in the human person. The distinction is important, but not one that puts the two concepts in opposition to one another, especially considering Nishitani's understanding that absolute emptiness is absolute fullness, and Rahner's description of the absolute fullness as an abyss.

Interreligious dialogue should not aim for a uniform concept of reality. The goal is not that all religions be identical, but rather that all religions be respectful of one another's differences while together seeking to further the common good of humanity. To that end it is helpful to put Rahner and Nishitani in dialogue with one another in order to give a response to the experience of meaninglessness in contemporary 
culture, an experience that too often results in dehumanization and violence instead of love.

\section{APPENDIX: ŚŪNYATĀ IN BUDDHISM ${ }^{68}$}

Buddhism is a religion that has seen not only the development of thought that occurs over time, but the development that results from the transplantation of thought into different cultures. Buddhism has developed both chronologically and geographically. The religion began in India during the 6th century BCE with the man Siddhärtha Gautama, a Hindu who became known as the Buddha or the awakened/enlightened one and who advocated "the middle way" between a life in the world and a life of asceticism. ${ }^{69}$ The roots of the concept of 'sinnyatā, or emptiness, can be found in the early Buddhist concepts of anātman and pratityasamūtpāda - that is, non-self and dependent co-origination. ${ }^{70}$ These two concepts advocate a mutual interdependence of all that exists and a negation of self as an independent subject. Hans Waldenfels describes them in correlation as "the idea that there is no such thing as an independent, self-supporting world substance; instead all beings in the world, in virtue of their dependency, have their being from and in dependency on one another." ${ }^{11}$

The concept of sínyata, incorporating the concepts of non-self and dependent co-origination, is given a central role in Buddhist thought and practice by the second century CE Mahāyāna Buddhist philosopher Nāgārjuna in the Mādhyamika school of Buddhism. Śं̄nyatā is understood in this school as absolute negation, including the negation of negation. All concepts are empty of meaning in the Mādhyamika school including the concept of śünyatā, therefore even to say śm unyatā is false. It is the idea of "not this, not that." As soon as one thinks one has understood, one has proved the level of one's misunderstanding. Abraham Vélez de Cea explains that for Nāgārjuna śünyatā has both a cognitive and an affective intent in which the "cognitive abandonment and relinquishing of views of absolute identity is inseparable from the affective cessation of attachment to the absolute identity of persons and things." 72 As Gregory Ornatowski points out, for Nāgārjuna śūnyatā has a mainly sotierological function. ${ }^{73}$ In other words, the concept has a practical intent, which is to negate all concepts of an "absolute reality" in order that his followers might experience absolute reality. Ornatowski states that "for Nāgārjuna 'emptiness' was thus ultimately a soteriological aid toward enlightenment, not a philosophy itself. By denying all points of view it was the assertion that only meditation and nonattachment to any views was the answer. Any attempt to construct a philosophy, especially a Western-style one, based upon emptiness should be impossible if one remains true to what seems to be Nāgārjuna's original intent. This is the fundamental contradiction within the thought of these three Kyoto-school philosophers [Nishida, Nishitani, and Abe]." ${ }^{74}$ For this reason, it is important to make a distinction between the original concept of śmnyatä found in the work of Nāgārjuna and the way the concept came to be understood in the Kyoto school. ${ }^{75}$ The Kyoto school, however, is drawing not simply on the concept of śünyatā as it was understood by Nāgārjuna, but on the way it has been historically and geographically developed. Within the Mãdhyamika school itself "Absolute Reality came 
to be ascribed to such notions as tathatā (suchness), tathägatagarbha (womb of Buddhahood), and dharmakaya (absolute truth body of the Buddha) and was viewed as what 'remained' after the radical 'emptying' of all things' substantive nature," 76 despite the fact that Nāgārjuna himself never used these terms.

One of the schools that developed out of the Mādhyamika school is the Yogāaara school (ca. $300 \mathrm{CE}$ ). The texts of this school become the focus of the Chinese Ch'an school (Zen in Japan). What is important to note in this development is that in the Yogācāra school, Nāgārjuna's concept of emptiness becomes identified with pure consciousness. ${ }^{77}$ Along with the Yogācāra texts, Zen emphasizes the older Wisdom Sutras that teach the formula form is emptiness and emptiness is form. ${ }^{78}$ In translating Nishitani's work, Van Bragt notes that "form" can be understood as "thing" in this equation and is related to Nishitani's formula of being is nothingness and nothingness is being. ${ }^{79}$

Having traced the important aspects of the concept of emptiness in the Buddhist lineage down to the Zen school, one arrives at the Kyoto school, to which Nishitani belongs. The Kyoto school simply designates "a way of philosophizing-more a philosophical ethos than a unified system of thought-which developed in the department of philosophy and religion at the State University of Kyoto under the initial inspiration of Kitarō Nishida (1870-1945)." ${ }^{80}$ Van Bragt describes the Kyoto school's basic characteristics as "a thoroughgoing loyalty to its own traditions, a committed openness to Western traditions, and a deliberate attempt to bring about a synthesis of East and West." ${ }^{81}$ It is in the context of this history that one can look at the concept of emptiness in Keiji Nishitani's work Religion and Nothingness.

\section{NOTES}

1. Masao Abe, "Kenosis and Emptiness," in Buddhist Emptiness and Christian Trinity: Essays and Explorations, ed. Roger Corless and Paul Knitter (New York: Paulist Press: 1990), 6.

2. Keiji Nishitani, Religion and Nothingness, trans. Jan Van Bragt (Berkeley: University of California Press, 1982), 88.

3. Abe, "Kenosis and Emptiness," 6.

4. References to Rahner's applicable works follow in the notes to section 2. It is noted here that any dialogue between Christianity and another religion must factor in Jesus Christ. While the scope of this article does not address the role of Christ in the Buddhist-Christian dialogue, several excellent works have been done relating the concept of emptiness in Buddhism to the concept of kenosis as it relates to Christ in Christianity. See Buddhist Emptiness and Christian Trinity, as well as Divine Emptiness and Historical Fullness: A Buddhist Jewish Christian Conversation with Masao Abe, ed. Christopher Ives (Valley Forge, PA: Trinity Press International, 1995) and Hans Waldenfels, Absolute Nothingness: Foundations for a Buddhist-Christian Dialogue, trans. by J. W. Heisig (New York: Paulist Press, 1980). For the perspective of an evangelical Christian dialogue partner for Nishitani's work, see Russell H. Bowers Jr., Someone or Nothing? Nishitani's Religion and Nothingness as a Foundation for Christian-Buddhist Dialogue, Asian Thought and Culture 27 (New York: Peter Lang, 1995).

5. It should also be noted that both men studied under Heidegger and that this common philosophical background most likely contributes to many of the similarities in the way they understand reality and the vocabulary they use to describe that reality. Unfortunately it is beyond the scope of this article to explore that connection any further. 
6. For a brief history of the concept of śünyatā in Buddhism that provides the background for Nishitani's work, see the appendix to this article.

7. For a more comprehensive account of the incomprehensibility of God in the Christian tradition, see the following articles by Karl Rahner in Theological Investigations, Vol. XVI: Experience of the Spirit: Source of Theology, trans. David Morland (New York: Crossroad, 1983): "The Hiddenness of God," 227-243, and "An Investigation of the Incomprehensibility of God in St. Thomas Aquinas," 244-254.

8. One must also note that the affective experience itself may vary due to the cognitive framework within which the experience occurs.

9. In the Stanford Encyclopedia of Philosophy, Brett Davis notes in his entry on the Kyoto school that "the Kyoto School is perhaps becoming, for better and for worse, more an object of scholarship than a predominantly living tradition. However, as with most schools of philosophy, the line between critical scholarship and creative appropriation is hardly a clear one, and in practice the retrospective study of the Kyoto School often blends together with its further development as a vibrant school of thought." Bret W. Davis, "The Kyoto School," The Stanford Encyclopedia of Philosophy (spring 2006 ed.), ed. Edward N. Zalta, http://plato.stanford .edu/archives/spr2006/entries/kyoto-school/.

10. See also Hase Shoto, "Nihilism, Science, and Emptiness in Nishitani," Buddhist-Christian Studies 19 (1999): 139-154, and the response to that article, Ryusei Takeda, "Religion and Science: Nishitani's View of Nihility and Emptiness-A Pure Land Critique," BuddhistChristian Studies 19 (1999): 155-163.

11. Nishitani, Religion and Nothingness, 4.

12. Ibid.

13. Ibid., 3.

14. Ibid.

15. Ibid., 2.

16. Ibid., 296.

17. Waldenfels, Absolute Nothingness, 16.

18. Nishitani, Religion and Nothingness, 99.

19. Ibid.

20. Ibid., 70 .

21. Ibid.

22. Ibid., 98.

23. Ibid., 60.

24. Ibid.

25. Ibid., 40-41.

26. Ibid., 99.

27. Ibid., 105-106.

28. Ibid., 37-38.

29. Ibid., 39.

30. Ibid.

31. Ibid., 40.

32. Ibid.

33. Ibid., 86.

34. Ibid., 87.

35. Ibid., 95-96.

36. Ibid., 96.

37. Ibid., 70.

38. Ibid., 71.

39. Ibid., 100-101.

40. Ibid., 102.

41. Ibid. 
42. Ibid., 60 .

43. Karl Rahner, "The Church and Atheism," in Theological Investigations, Vol. 21: Science and Christian Faith, trans. Hugh Riley (New York: Crossroad, 1988), 148.

44. Ibid.

45. Karl Rahner, "Thoughts on the Possibility of Belief Today," in Theological Investigations, Vol. 5: Later Writings, trans. Karl-H. Kruger (Baltimore: Helicon Press, 1966), 5-6. Hereafter cited as TI 5:1.

46. Ibid., 6 .

47. Ibid.

48. It must be noted here that Rahner does not see science as incompatible with religion or as somehow inherently evil. His critique here simply regards one way in which modern science and technology has been used.

49. Karl Rahner, "Christian Living Formerly and Today" in Theological Investigations, Vol. 7: Further Theolgogy of the Spiritual Life I, trans. David Bourke (London: Darton, Longman and Todd, 1971), 12. Hereafter cited as TI 7:1.

50. For example, the news recently carried a story about Catholic bishops in England trying to formulate a response to possible legislation in the United Kingdom that would allow the creation of embryos that are human chimeras (injecting animal DNA into human embryos to create an animal/human hybrid) for the purposes of research, so long as they were not implanted and were destroyed within two weeks. While standing firmly against the creation of such beings, the bishops nonetheless concluded that having partial animal genetic material did not negate the right to life involved if the being also had part or mostly human genetic material. Jonathan Petre, "Chimera Embyros Have Right to Life, Say Catholic Bishops," Telegraph. Co.UK, http://www.telegraph.co.uk/news/main.jhtml?xml=/news/2007/06/26/nchimera126 .$x \mathrm{ml}$, accessed June 30, 2007.

51. Karl Rahner, "The Human Question of Meaning in Face of the Absolute Mystery of God," in Theological Investigations, Vol. 18: God and Revelation, trans. Edward Quinn (New York: Crossroad, 1983), 99. Hereafter cited as TI 18:5.

52. Rahner does not advocate such a choice as the result of blind faith, but rather sees such a leap of faith as always grounded by human reason.

53. TI 18:5, 92, 94, 98.

54. Ibid., 98.

55. TI 7:1, 15 .

56. $T I 5: 1,7$.

57. Karl Rahner, "Justifying Faith in an Agnostic World" in TI 21, 134. Hereafter cited as $T I 21: 8$.

58. TI $21: 8,135$.

59. $T I 5: 1,8$.

60. TI 21:8, 135 .

61. Karl Rahner, "Thomas Aquinas on the Incomprehensibility of God," Journal of Religion 58 supplement (1978): S124.

62. Ibid.

63. Karl Rahner, "The Experience of Self and the Experience of God," in Theological Investigations, Vol. XIII: Theology, Anthropology, Christology, trans. David Bourke (New York: Seabury, 1975), 127 (hereafter cited as TI 13:8).

64. Karl Rahner, The Love of Jesus and the Love of Neighbor, trans. Robert Barr (New York: Crossroad, 1983), 99-100.

65. Ibid., 103-104. Again I refer the reader to the work that has been done relating the kenosis of Christ to the concept of "emptiness" in the Kyoto school of Buddhism. See footnote 4 above.

66. Karl Rahner and Wilhelm Thüsing, A New Christology, trans. David Smith and Verdant Green (New York: Seabury Press, 1980), 15. 
67. Rahner, TI 13:8, 127.

68. For more information, see Frederick J. Streng, Emptiness: A Study in Religious Meaning (Nashville, TN: Abingdon Press, 1967) and T. R. V. Murti, The Central Philosophy of Buddhism (London: George Allen and Unwin, 1960).

69. Theodore de Bary, ed., The Buddhist Tradition in India, China and Japan (New York: Random House Vintage Books, 1969), 6.

70. Hans Waldenfels, Absolute Nothingness: Foundations for a Buddhist-Christian Dialogue, trans. J. W. Heisig (New York: Paulist Press, 1980), 8-14.

71. Ibid., 14.

72. Abraham Vélez de Cea, "A New Direction for Comparative Studies of Buddhists and Christians: Evidence from Nāgārjuna and John of the Cross," Buddhist-Christian Studies 26 (2006): 148.

73. Gregory Ornatowski, “Transformations of 'Emptiness': On the Idea of Ś'̄nyatā and the Thought of Abe and the Kyoto School of Philosophy," Journal of Ecumenical Studies 34 (1997): 95.

74. Ibid., 103.

75. See Ornatowski, 100-103, for an account of four major contrasts between the concept as it is used by Nāgārjuna and the way it is used in the Kyoto school.

76. Ibid., 95. See also note 12.

77. Waldenfels, 25.

78. Ibid., 26. For a more detailed account of this development, especially the development of the Yogācāra school of thought in China under the influence of Chi-I and Fa-tsung, see Ornatowski, 96-99.

79. Nishitani, Religion and Nothingness, 297, 303. Nishitani uses the Latin sive here, which could also be expressed as qua and is meant to imply a reciprocal relationship (303).

80. Ibid., "Translator's Introduction," xxviii.

81. Ibid. 